\title{
EDITORIAL
}

\section{Exceptionalism and globalism}

\author{
John Cairns, Jr* \\ Department of Biology, Virginia Polytechnic Institute and State University, 1020 Derring Hall, Blacksburg, Virginia 24061, USA
}

\begin{abstract}
Achieving sustainable use of the planet will require ethical judgments in both sciences and environmental politics. The purpose of this editorial is to discuss two paradigms, exceptionalism and globalism, that are important in this regard. Exceptionalism is the insistence that one set of rules or behaviors is acceptable for an individual or country but that a different set should be used for the rest of the world. For example, the disparity in per capita consumption of resources and economic status has increased dramatically in the last century, but the consumers of great amounts of resources do not feel a proportionate responsibility for addressing this issue. Globalism is defined as individual and societal willingness to diminish, postpone or forgo individual natural resource use to protect and enhance the integrity of the global ecological life support system. Increasing affluence and the still increasing human population, coupled with wide dissemination of information and an increasing awareness that humans occupy a finite planet, exacerbate this already difficult situation. Increased interest in sustainable use of the planet makes open discussion of these issues mandatory because individuals cannot function in isolation from the larger society of which they are a part. Similarly, no country can function in isolation from other countries, which collectively form an interactive mosaic. This discussion identifies some of the crucial issues related to exceptionalism and globalism, which must be addressed before sustainable use of the planet can be achieved.
\end{abstract}

KEY WORDS: Environmental ethics · Globalism, Individualism · Exceptionalism · Sustainable development $\cdot$ Economic growth

- Resale or republication not permitted without written consent of the publisher

\section{Sustainability}

A commonly held belief is that, the more distant a problem is in time or space, the less attention it receives. However, sustainable use of the planet (more popularly referred to as sustainable development) requires serious attention to matters involving both large temporal and spatial spans. The dominant paradigm is perpetual economic growth, which is an oxymoron for inhabitants of a finite planet. Sustainability will require a major paradigm shift, which will be invariably painful during the transitional period. Denial that the problems exist will only make matters worse because serious issues will remain unaddressed. Globalism is defined as individual and societal willingness to diminish, postpone or forgo individual natural resource use to protect and enhance the integrity of the global eco-

*E-mail: jcairns@vt.edu logical life support system and is the sine qua non of sustainable use of the planet.

\section{Ecological footprint}

Wackernagel \& Rees (1996) have documented the grossly disproportionate per capita consumption of natural resources (ecological 'footprint' size). Public debate about the responsibility for this situation is remarkably muted in those countries with the highest per capita consumption. These consumers act as if they are exempt from responsibility, although they are well aware of the devastation of tropical rain forests and other natural systems. No political candidate would dare break the taboo and urge public discussion of this issue! Yet some politicians claim to favor 'smart growth,' 'sustainable development,' and other descriptors of sustainable use of the planet. 


\section{Exceptionalism}

Exceptionalism is insisting that one set of rules or behaviors is acceptable for a particular individual or country but that a different set should be used for the rest of the world. For example, United Nations Secretary General Kofi Annan has noted that over half the world's humans have neither placed nor received a telephone call. At the same time, talking on a cellular phone while driving has become a major issue in the United States where ownership of automobiles is drastically different from much of the rest of the world's population. The ethical issue becomes: would humans be living in a sustainable world if the entire world replicated American ownership of automobiles, cellular phones, and other material goods? If not, should citizens of the United States and other developed countries cease to act as if they were entitled to exceptional treatment? Sustainable use of the planet almost certainly requires a universal ethos or set of guiding beliefs and values. Exceptionalism, as practiced, flaunts this requirement. It and exemptionalism (the belief that human technology, creativity, and ingenuity exempt humans from the biophysical laws that limit and control other species) are, arguably, the most formidable obstacles to sustainable use of the planet. Further, since the United States is the planet's only superpower, other nations will assume that its behavior is sustainable for other portions of the planet.

\section{The deadly duo: exceptionalism and exemptionalism}

Exemptionalism (Cairns 1999) assumes that human technology, creativity, and ingenuity exempt humans from the iron laws of nature that limit other species. In this view, resource depletion is not a problem because an infinite number of substitutes can be found or created. The minority view of environmentalism asserts that leaving a habitable planet for future generations requires major attention to the health and condition of the ecological component of Earth's life support system and is concerned about resource depletion.

The planet is in the grip of a tyranny of small individual decisions, which in isolation appear insignificant but collectively may, at times, have severe and unpleasant consequences. This phenomenon was noted many years ago by economist Kahn (1966) and more recently by ecologist Odum (1982). Arguably, failure to appreciate the adverse impacts of multitudes of small decisions may be the cause of many acts that collectively harm natural systems and, ultimately, human society.

It is essential to emphasize also the positive power of aggregate individual decisions that, in isolation from others, seems futile. Sustainable use of the planet is based on the assumption that large numbers of environmentally sensitive small decisions will result in leaving a more habitable planet for future generations. The degree to which each individual modifies personal decisions because of eco-ethics, rather than deciding on purely self interest, will determine the fate of the planet's ecological life support system. This paradigm shift requires both a substantive improvement in environmental literacy and the development of a new societal ethos (or value system) based on an acknowledgment of human dependence on natural systems and an acceptance of an ethical responsibility for the fate of fellow species.

Exemptionalists make three primary assumptions: (1) humans are the superior species and their 'needs' transcend those of other species, (2) some humans excel in acquiring material resources and are entitled to as much as they can gather, and (3) resources are infinitely substitutable (e.g., Simon 1981) and, therefore, are available in unlimited quantities to those humans with the ingenuity, creativity, and energy to acquire them. Acceptance of these articles of faith obviates any ethical responsibility for one's fellow humans or fellow species. The word faith seems appropriate because as Dobzhansky (1945) noted 'It appears, however, that no evidence is powerful enough to force acceptance of a conclusion that is emotionally distasteful.'

Those who act on the assumption that humans are dependent upon an ecological or biospheric life support system do so as an act of faith. Sciences alone will not suffice! This concept is why a set of eco-ethical values is essential. Faith, not evidence, is the basis for each position - scientific evidence is used selectively to bolster each position.

Faith, however, is far from a perfect shield against unpleasant consequences. Wealthy exemptionalists (e.g., Lardner 2000) might well note the Durants' (1968) caution that concentration of wealth is natural and inevitable and is periodically alleviated by violent or peaceable partial redistribution at the biospheric level. Global warming, antibiotic resistant species, and anthropogenic environmental endocrine disrupters are illustrative of the unpleasant consequences of a paucity of eco-ethical values.

Economic growth is more popular than ever at a global level despite persuasive contrary evidence (e.g., Hodson 1972, Hardin 1992, Douthwaite 1999) that appears to have had little or no effect upon the economic/technological juggernaut. Obviously, restraining the materialistic 'good life' is so distasteful that contrary evidence is ignored or denied. Eco-ethics appears to be the best way to avoid the very unpleasant environmental consequences for which evidence is mounting rapidly. 


\section{The crime of exuberant optimism}

Tanner (1981) proposed the following regarding environmental education: (1) most people only want to hear good news, (2) they want to trust anyone who is speaking positively or bearing good news, and (3) the members of the general public decide on issues based upon their judgment/trust of the speaker, rather than on facts or knowledge. When confronted with massive evidence that predicts dire consequences if a present trend continues, a common response is 'I remain optimistic.' Usually no substantive supporting evidence is offered, nor is it generally required. The irony is that the speakers consider themselves to be intellectuals, although ignoring evidence is a decidedly anti-intellectual position. Ballantyne \& Parker (1996) advocate constructivism, which emphasizes a qualitative change in the understanding of the learner, rather than increasing the amount of knowledge. A successful environmental education approach interrelates knowledge, attitudes/values, and behaviors. Cairns (1994, 1998) espouses recognizing that human society and natural systems are co-evolving, each affecting the other. Regrettably, most humans perceive themselves as separate from the environment and its problems and, therefore, are unable to connect personal responsibility to potential solutions (e.g., Gigliotti 1992). The National Research Council (1994) concluded that immediate and constant feedback may fail to optimize performance - an important observation in the quest for sustainable use of the planet. The National Research Council (1991) notes that delayed and intermittent feedback may produce superior performance because it allows learners to detect and correct errors. These findings are important considerations in the development of an eco-ethic.

\section{Eco-ethics and the perception of close connections}

Sustainable use of the planet requires delaying or reducing use of resources to obtain gratification for the benefit of future generations as well as presently disadvantaged persons, that is, unless either the present disparity in natural resource use per capita is considered acceptable or one believes that per capita resource use for all can be brought to the levels of the presently advantaged without irreparable harm to natural systems. Present evidence indicates that environmentally responsible actions involve simpler living that places less pressure on natural systems. Wackernagel \& Rees (1996) discuss this at considerable length and reach two important conclusions: (1) reducing the size of the human ecological footprint can increase the quality of life and (2) efficiency savings do not neces- sarily reduce ecological footprint size unless the savings are captured for investment in natural capital rehabilitation.

It is abundantly clear that there is often a substantial gap between professed beliefs and actual behavior. The integrated causal model of Barkow et al. (1992) and various social exchange theories propose that humans are more likely to behave altruistically when the recipient of the behavior is closely connected or similar (kin, peer) and when the potential for reciprocal altruism exists. Increased social status also helps, although an uncharitable person might not regard such an act as altruistic. However, present societal actions, with some notable exceptions, do not indicate feelings of closeness to either natural systems or future generations.

Cutler (1999) believes society has made a religion of materialism and property rights to the detriment of natural systems. In fact, much activity that results in environmental damage is subsidized by governments (Myers \& Kent 1998). Naturally, special interest groups receiving these subsidies make every effort to suppress discussion of adverse effects upon human health and the environment. Failing that, attempts are made to denigrate those who point out the adverse effects. A classic case was the reaction to Carson's (1962) Silent Spring. This courageous woman, bravely describing her soon to be fatal illness as arthritis, was ridiculed as a 'gloom and doomer,' too emotional for a scientist, and, arguably worst of all, for venturing into subjects not suitable for a woman. The names of the denigrators have long been forgotten (except by those of us who witnessed the battle), but Carson is an icon of the environmental movement. Her efforts show that eco-ethics may yet prevail. Still, Ehrlich \& Ehrlich (1996) illustrate well that the battle for an ethical relationship with the biosphere is far from over. In fact, there may well be a far more serious problem than well-funded special interest groups.

\section{Toppling taboos}

A taboo is a prohibition excluding something from use, approach, or mention because of its sacred and inviolable nature (American Heritage Dictionary). Many years ago, I naively became finance chair of a religious organization and found that frank discussion of individual contributions was taboo. Yet, most members were associated with (even owners of) business organizations where 'cash flow' was a dominant item in most discussions. Hardin's (1996) superb book on this subject should be required reading for everyone interested in eco-ethics. As Hardin notes, few, if any, objects are taboo for touching. However, in the United States at least, one's actions in touching another per- 
son, except for the traditional handshake, may be misunderstood and result in legal action. Touching another person has become more taboo in the U.S. than it was just a generation ago. It is now a matter of considerable legislation, despite abundant evidence of the health value of many forms of physical contact. Most other primates spend much time grooming each other, removing fleas, etc. Now that fleas are less common on humans and motives in touching others less obvious, a strong taboo is developing.

For eco-ethicists, Hardin's injunction to never tackle more than one taboo at a time is daunting. If one believes that everything in nature is interconnected, how can one focus on a single connection? If, as Hardin recommends, one diminishes the element of surprise (for example, by sending copies of a talk to the news media), a multidimensional approach would likely result in confusion and misunderstanding. The most important objective should be to identify the taboos clearly and stalk them in a systematic and orderly fashion. However, before this concept can be implemented, there is another obstacle to overcome.

\section{Diminishing denial}

Homo sapiens has a tremendous capacity for denial despite the species description. Humans deny the death of a person important in their lives, or the existence of a terminal illness, or that cigarette smoking may cause health problems. In some societies (e.g., the U.S.), the aging process is denied with euphemisms such as 'senior citizens' and ' 80 years young.' Not surprisingly, denial is also a common means of avoiding the ethical issues concerning the relationship between human society and the biosphere. If issues are ignored or humans pretend they do not exist, perhaps they will go away. Or, more subtly, humans may preach respect for the interdependent web of life and acknowledge that they are a part of it, but practices continue to injure the relationship. Environmentalists jet all over the planet to espouse environmental sensitivity and meet in places quite distant for most (e.g., the Rio Conference) to discuss the best way to address environmental problems. Make no mistake, an honest selfappraisal will certainly reveal that everyone practices denial to some degree. Doubtless, Hardin's advice about taboos applies equally well to denial, that is, address only one form of denial at a time, both at a societal and individual level. As a society, would it hurt to admit that anthropogenic-induced global warming is a distinct possibility and to consider policies that diminish greenhouse gases? Or, at the individual level, is a petrol-guzzling sport utility vehicle (SUV) an environmentally sensitive way to visit natural systems?
Orr \& Ehrenfeld (1995) have a splendid, concise analysis of the denial problem, and Hardin (1998) has produced the definitive book on this subject while simultaneously showing that society need not flow inevitably into environmental chaos. A great companion book is Douthwaite (1999) since it addresses the denial that economic growth, especially at the global level, can impoverish many humans and endanger natural systems at the same time.

Denial is such an attractive way of not facing problems head-on and is so socially and politically acceptable that it is difficult to imagine that it will be banished forever! However, diminishing denial is essential to both the survival of the human species and improving the quality of life in this new century.

\section{Hope from the business community}

Hawken et al. (1999) link environmentally sensitive business practices with profitability and bolster this point with numerous case histories. Nattrass and Altomare (1999) espouse the idea that a company should take on the additional responsibility of social and environmental degradations, which they describe as the evolutionary corporation. These corporations are placed in a curious position because, arguably, business has been labeled the major source of most environmental problems. Yet, correcting problems at the source dramatically enhances the probability of success. Weston (1995) has produced an insightful book on the integration of ecological concepts into industrial operations. Clearly, some businesses would rather spend money on protracted legal battles than on addressing the problems. Regrettably, they are supported by politicians and citizens fearful of losing campaign funding, tax dollars, or jobs, and news media fear loss of advertising revenue. Worst of all may be the 'When on the Titanic, go First Class' attitude. However, a sense of community may yet triumph over exceptionalism, and ethical issues may yet become a dominant factor in societal decisions.

\section{Conclusions}

Exceptionalism is a major obstacle to a fair, equitable, and non-degrading 'use without abuse' policy for global environmental resources. Exceptionalism is socially acceptable and is primarily a consequence of the denial of the problems, both human and environmental, that it causes. When coupled with exemptionalism, the effects can be devastating. The situation is further exacerbated by the failure to accept that similar, seemingly insignificant small decisions, if suffi- 
ciently numerous, can exert a tyranny or enhance prospects for sustainable use of the planet, depending on their nature. Optimism is an essential attribute of the human condition; however, exuberant optimism that denies evidence and abandons reason is very dangerous. The development of an environmental ethos as a set of guiding eco-ethical values, a perception of connectedness between human society and the environment, and a concomitant perception of connections with future generations are essential to sustainable use of the planet. In order for a meaningful discussion to take place on these issues, many taboos must be toppled and denials diminished. There is every reason for optimism about what could be done to address these problems, but persuasive reasons for pessimism about what will be done.

Acknowledgements. I am deeply indebted to Karen J. Cairns for crucial help on the literature in environmental education. Charles A. Kennedy and Alan Heath provided useful comments on the first draft. Extensive correspondence with Peter Leigh on a broad array of environmental issues has markedly influenced this manuscript although, of course, he is not responsible for any errors in my analysis. I am indebted to Eva Call for transcribing my handwritten draft, and Darla Donald provided her usual skilled editorial assistance. The Cairns Foundation paid for the cost of producing this manuscript.

\section{LITERATURE CITED}

Ballantyne, R. R. and Parker, J. M. (1996) Teaching and learning in environmental education: developing environmental conceptions. J. Environ. Ed. 27(2):25-32

Barkow, J. H., Cosmides, L. and Tooby, J. (ed.) (1992) The Adapted Mind: Evolutionary Psychology and the Generation of Culture. New York: Oxford University Press

Cairns, J., Jr. (1994) Ecological restoration: re-examining human society's relationship with natural systems. The Abel Wolman Distinguished Lecture. Washington, DC: National Academy of Sciences

Cairns, J., Jr. (1998) Malthus revisited: sustainability and the denial of limits. The Social Contract VIII(3):157-167

Cairns, J., Jr. (1999) Exemptionalism vs. environmentalism: the crucial debate on the value of ecosystem health. Aquat. Ecosyst. Health Manage. 2:331-338

Carson R. (1962) Silent Spring. Cambridge, PA: Riverside Press

Cutler, M. R. (1999) The religion of materialism: property rights and other aspects of our culture that lead us down the path to environmental disaster. The Highlands Voice 32(12):1, 13, 18
Dobzhansky, Th. (1945) Review of Evolution, Creation, and Science by F. L. Marsh. Am. Nat. 79:73-75

Douthwaite, R. (1999) The Growth Illusion. Gabriola Island, British Columbia, Canada: New Society Publishers. 383 pp

Durant, W. and Durant, A. (1968) The Lessons of History. New York: MJF Books. 117 pp

Ehrlich, P. and Ehrlich, A. (1996) Betrayal of Science and Reason: How Environmental Anti-Science Threatens Our Future. Washington, DC: Island Press

Gigliotti, L. M. (1992) Environmental attitudes: 20 years of change? J. Environ. Ed. 24(1):15-26

Hardin, G. (1992) Living Within Limits. Oxford, England: Oxford University Press. 339 pp

Hardin, G. (1996) Stalking the Wild Taboo. Petoskey, Michigan: The Social Contract Press. $376 \mathrm{pp}$

Hardin, G. (1998) The Ostrich Factor : Our Population Myopia. Oxford, England: Oxford University Press. 163 pp

Hawken, P., Lovins, A. and Lovins, H. (1999) Natural Capitalism: Creating the Next Industrial Revolution. New York: Little, Brown \& Co., Publishers. 306 pp

Hodson, H. V. (1972) The Diseconomics of Growth. New York: Ballantine Books. $239 \mathrm{pp}$

Kahn, A. E. (1966) The tyranny of small decisions: market failures, imperfections, and the limits of economics. Kyklos 19:23-47

Lardner, J. (2000) The rich get richer: what happens to American society when the gap in wealth and income grows larger? U.S. News World Report 128(7):38-43

Myers, N. with Kent, J. (1998) Perverse Subsidies: Tax \$s Undercutting Our Economies and Environments Alike. Winnipeg, Manitoba, Canada: International Institute of Sustainable Development. 230 pp

National Research Council (1991) In the Mind's Eye: Enhancing Human Performance. Washington, DC: National Academy Press. 304 pp

National Research Council (1994) Learning, Remembering, Believing: Enhancing Human Performance. Washington, DC: National Academy Press. 416 pp

Nattrass, B. and Altomare, M. (1999) The Natural Step for Business: Wealth, Ecology and the Evolutionary Corporation. Gabriola Island, British Columbia, Canada: New Society Publishers. $222 \mathrm{pp}$

Odum, W. E. (1982) Environmental degradation and the tyranny of small decisions. BioScience 32(9):728-729

Orr, D. W. and Ehrenfeld, D. (1995). None so blind: the problems of ecological denial. Conserv. Biol. 9(5):985-987

Simon, J. (1981) The Ultimate Resource. Princeton, NJ: Princeton University Press

Tanner, T. (1981) Trust me. J. Environ. Ed. 12(3):43-44

Wackernagel, M. and Rees, W. (1996) Our Ecological Footprint: Reducing Human Impact on the Earth. Gabriola Island, British Columbia and Stony Creek, CT: New Society Publishers. $160 \mathrm{pp}$

Weston, R. F. (1995) Sustainable development: to better understand the concept. The Weston Way 21(1):5-16

Published on the Web: 27.03.2001 